\title{
Szabó Miklós[1]: A kisebb súlyú cselekmények elmélettörténete. Árva Zsuzsanna: Fejezetek a közigazgatási büntetőbíráskodás elmélettörténete köréből, DE-ÁJK, Debrecen, 2008. 327. oldal
}

Debreceni Jogi Mühely, 2009. évi (VI. évfolyam) 2. szám (2009. április)

2008-ban jelent meg a Debreceni Egyetem Állam- és Jogtudományi Kara kiadásában Árva Zsuzsanna 2007-ben megvédett doktori disszertációjának bővített változata könyv formájában.

A könyv a közigazgatási büntetőbíráskodás elmélettörténetét dolgozza fel. A cím előrevetíti a munka átfogó jellegét, hiszen a közigazgatási büntetőbíráskodás a kihágások és a szabálysértések közös megnevezésére létrehozott kifejezés, ahogyan ezt a fogalmi alapvetés címet viselő fejezet is meghatározza Máthé Gábor tanulmánya alapján. A szerző a jogterület egyes jellemző terminusait az értékes összevetést tartalmazó bevezető részben próbálja tisztázni. Ebben olyan többértelmü fogalmak összehasonlító kutatáson alapuló meghatározását adja, mint a közigazgatási büntetőbíráskodás, a közigazgatási büntetőjog, vagy a rendőri kihágások, illetve a rendőri büntetőbíráskodás.

A mü struktúrája hármas, míg a feldolgozás iránya kettős, esetenként hármas jellegü. A tématerület legszorosabban a közigazgatási joghoz kötődik, de a quasi bíráskodás karakternek köszönhetően alkotmányjogi elveket is szükséges figyelembe venni és ezt egészíti ki az 1955 előtti időszakban a büntetőjogi szabályozás - a büncselekmények trichotomikus felosztása okán.

A munka a kihágások és a szabálysértések hazai elmélettörténetét csaknem kezdetektől fogva végigköveti. A szerző a közigazgatási büntetőbíráskodás fejlődése során három nagy korszakot különböztetett meg, amely az elmélettörténet egy sajátos, részben alkotmányjogi aspektusának volt köszönhető. Így külön egységet képez a teljes történeti alkotmány fejezete, amelyben ugyan körvonalazódnak bizonyos alapelvek, ám a kihágások büntetőjogi kötődése a jogszabályok alapján megkérdőjelezhetetlen. A második átmeneti jellegü időszakban elemzi a kartális alkotmány jogterületre gyakorolt hatását, majd az államigazgatásba sorolt joganyag kódexben történő megerősítését. A harmadik és egyben utolsó rész a szabálysértési jog első és második kódexének elméletét dolgozza fel egyes de lege ferenda javaslatokkal.

Az első egy igen összetett fejezet, amely a történeti alkotmány kihágási szabályait és az ahhoz kapcsolódó elméletet mutatja be. Részletesen elemzi a jogszabályokat (II. 2. fejezet), foglalkozik az 1879-ben született Kihágási büntetőtörvénykönyvvel és más jogszabályokkal, valamint a kodifikációs kísérletekkel. Ez utóbbi rész megelőzi az elméleti feldolgozást, amely logikai szempontból indokolható, hiszen az elméleti irodalom kritikai szempontú bemutatása során szükséges visszautalni az adott korszakban hatályos szabályokra, amelyek esetenként az elmélet tarthatatlanságát vagy helyességét igazolják. A fejezet különválasztja a büntetőjogi és a közigazgatási irodalmat, bár a rend olykor szükségszerüen felborul, hiszen a kihágások más súlyosabb bűncselekményektől való elhatárolásának szempontja a közjogászokat és a büntetőjogászokat egyaránt foglalkoztatta.

A büntetőjogi megközelítés ismerteti a kihágások mennyiségi és minőségi elkülönítését valló elméleteket (II. 3. fejezet), míg a közigazgatási rész (II. 4. fejezet) rámutat az általános közigazgatási szankciókkal való összefüggésre. A szerző e körben különválasztja a kihágásokat a rendészethez és a kényszerhez kötő elméleteket, és felhívja a figyelmet, hogy a jogterület továbbfejlesztése kapcsán ma is hasonló problémák merülnek fel. 
A lektori vélemény szerint is tudományelméletileg a munka leginkább újszerű fejezete az írott alkotmány megszületése és az első szabálysértési kódex hatálybalépése közötti korszak bemutatása (III. fejezet). Ekkor ment végbe a közigazgatási büntetőbíráskodás legjelentősebb reformja, amely a kihágásokat megszüntetve a cselekmények igen jelentős hányadát csaknem változatlanul strukturálta át a büntetőjogból a közigazgatási jogba. 1949 után több szempontból is meghatározó változások következtek be a jogintézmény életében. Alkotmányjogilag elsődlegesnek az írott alkotmány elfogadása tekinthető, amely deklarálta az igazságszolgáltatás bírói monopólium elvét. Ugyanakkor az önkormányzati rendszer megszüntetése nyomán létrejövő tanácsi szervek hatáskört kaptak az akkor még egyértelműen a büntetőjogba tartozó cselekmények elbírálására. A cselekmények államigazgatási felelősséggé átminősítésével összefüggésben a szerző olyan jogpolitikai aspektusokra is felhívja a figyelmet, mint a szovjet jogalkotás vagy a Magyar Dolgozók Pártja döntéseinek közvetlen hatása a megszülető jogszabályokra.

A fejezet vázolja a kihágások, valamint az egyre inkább terjedő államigazgatási szankciók összefüggéseit, és az egyes - kezdetben büntetőjogba utalt - cselekmények már ekkor észrevehető visszarendeződését. A korabeli folyóiratokat feldolgozva az elméleti szerzők munkáin keresztült ismerteti meg az 1968. évi I. tv. kialakulásának történetét, illetve meghatározza, hogy a kódex alkotása során milyen csomópontok mentén zajlottak a viták.

A harmadik fejezet már az 1968-as és az 1999-es kódex szabályaival összefüggő elméleti rész, ahol - az első fejezettel ellentétben - a szerző a jogszabályok bemutatásától szinte teljesen eltekint. Ehelyett arra a szinte folyamatos dekriminalizációra helyezi a hangsúlyt, amelynek köszönhetően sorra jelentek meg a szabálysértéseken belül a jellemzően büntetőjoghoz kötődő cselekmények. A visszarendeződés egyrészt előtérbe helyezte a szabálysértések és a büntetőjog kapcsolatának tudományelméleti vizsgálatát és előhívta az elterelési és visszaterelési elméleteket, amelyek különösen a hatályos törvény elökészítése előtt váltak ismét aktuálissá. A folyamatot erösítette a büncselekmények 1971-ben történt kettéválasztása, amely ismét a büntetőjog belső megosztottságára és a külső elterelés lehetséges eszközeire helyezte a hangsúlyt.

A szerző részletesen bemutatja a rendszerváltás után bekövetkező erőteljes változásokat. Kitér az Emberi jogok és alapvető szabadságok védelméről szóló egyezményhez történő csatlakozás közvetlen következményeire. Bittó Márta szakvéleménye alapján számba veszi az ún. strasbourgi büntetőügy-fogalom elemeit, vázolja a közvetlenül összefüggő bírósági gyakorlatot és nem mulasztja el a Belügyminisztérium reflexióját sem közölni. Az egyezmény hatása azonban javarészt a nevezetes 63/1997. (XII. 12.) alkotmánybírósági határozattal összefüggésben mutatkozott meg. E körben a szerző szerkezetileg különválasztja az alkotmányjogi testület szabálysértési ügyekkel kapcsolatos gyakorlatát, valamint az említett határozatot, ami első látásra megnehezíti az olvasó tájékozódását (IV. 6. fejezet $\mathrm{B}$ és $\mathrm{E}$ alpontja). A szerző álláspontja viszont annyiban védhető, hogy az említett döntést érdemes kiemelni a sorból, hiszen ennek közvetlen következményeként, és iránymutatása alapján született meg a hatályos jogi szabályozás.

A szerző az 1997-ben született határozat kritikai elemzését végzi el. Nemcsak részletesen bemutatja annak sarkalatos pontjait, hanem kitér a jelentős különvéleményekre és párhuzamos indokolásokra, továbbá a határozattal kapcsolatban született jogirodalmi véleményekre, amelyek esetenként egymásnak is ellentmondóak. Ezek között a szerző a Sólyom László, Németh János és Lábady Tamás által jegyzett párhuzamos indokolásban foglaltak mellett teszi le a voksát, több más szerzővel együtt; ezt az álláspontját jogszabályi és elméleti hivatkozásokkal külön is megindokolja. 
Az összegzés (V. fejezet) előtt elemzi a hatályos jogszabály anyagi és elméleti rendelkezéseit, a büntetőeljárással összefüggő elveket, valamint a meghatározónak tekintett külföldi szabályozást. Ezek közül elsőként a német rendszert vázolja, amely a hatályos jogfejlődés tükrében megalapozott. Itt előbb a német szabálysértési jog kialakulásával, az 1952-es törvénnyel foglalkozik, majd részletezi az 1968-as kódex rendelkezéseit. Ennek során részben a hatályos - 2005- ben módosított - törvényre, részben annak kommentárára támaszkodik és csak mögöttes anyagként használja fel a magyar jogirodalomban megjelent, egyébként is kevés számú tanulmányt. A másik meghatározó rendszer a francia, és alternatív utat képez az angol szabályozás, ahol a közjog és magánjog különválasztásának hiánya miatt elkülönült szabálysértési jogról nem igazán beszélhetünk. Ez utóbbi inkább a békebírói szisztéma meghonosítására adhatna alapot, amelynek ugyan voltak kísérletei Magyarországon még 1869-től kezdődően, ám az végül minden törekvés ellenére sem szilárdult meg.

A könyv de lege ferenda javaslatokkal zárul. Itt a szerző részletesen összeveti az elterelési és visszaterelési koncepciót, vázolva mindkét megoldás előnyeit és hátrányait. Több más szerzővel együtt végül az előbbi mellett foglal állását, ami valójában az egyetlen logikus és kivitelezhető megoldás. A jogterület kettős megosztottságát választva kiindulópontul, végigvezeti az anyagi és eljárási szabályozás lehetséges irányát, a fórumrendszert, valamint felhívja a figyelmet egyes garanciális követelményekre, így például a leegyszerüsítő jellegü szabályozásból fakadó anomáliákra.

A müvet elolvasva kevés hiányérzetünk támadhat, bár a szerző meglehetős óvatossággal a cím alapján csupán egyes fejezetek feldolgozását ígéri. Ezen vállalást azonban maradéktalanul teljesíteni is tudta, hiszen a kezdetektöl napjainkig követte az elmélettörténetet - a szakirodalom szinte teljeskörü feldolgozása mellett, amelyet a kidolgozott lábjegyzetapparátus és a felhasznált irodalom impozáns jegyzéke is bizonyít. A munka vállaltan nem vizsgálja az egyes jogszabályi rendelkezések hatályosulását, ami terjedelmi korlátokra tekintettel mindenképpen indokolt. A hiányosságként esetleg említhető körülmények - így például a fórumrendszer részletesebb elemzése, közte a hazai békebírói rendszer történetével, vagy más nemzetközi megoldások ismertetése - szintén a közigazgatási büntetőbíráskodás egy más megközelítési módját jelentették volna.

A könyv - a lektori előszónak is megfelelően - jó szívvel ajánlható gyakorló jogászoknak, a témával jobban megismerkedni kívánó egyetemi hallgatónak és a szabálysértések iránt érdeklődő más személyeknek, akik akár a jogalkalmazó munkához is hasznos adalékokat kaphatnak Árva Zsuzsanna könyvéböl.

[1] Címzetes egyetemi docens, Debreceni Egyetem Állam- és Jogtudományi Kar, Alkotmányjogi Tanszék 